\title{
Antioxidant and Cytotoxic Activity Studies of Sulfur Containing Glycine Imine Derivatives MCF-7 and DLD-1 Cell Lines
}

\author{
Seda Mesci ${ }^{1}$ (D), Melek Gul 2,3 (D), Tuba Yildirim ${ }^{3,4}$ (D) \\ ${ }^{1}$ Hitit University, Scientific Technical Application and Research Center, Corum, Turkey. \\ ${ }^{2}$ Amasya University, Faculty of Arts and Sciences, Department of Chemistry, Amasya, Turkey. \\ ${ }^{3}$ Amasya University, Institute of Science, Department of Biotechnology, Amasya, Turkey. \\ ${ }^{4}$ Amasya University, Faculty of Arts and Sciences, Department of Biology, Amasya, Turkey.
}

Correspondence Author: Seda Mesci

E-mail: sedamesci@gmail.com

Received: $30.08 .2020 \quad$ Accepted: 29.12 .2020

\section{ABSTRACT}

Objective: To investigate the antioxidant and cytotoxic activities of sulfur-containing glycine imine derivatives MCF-7 (human breast adenocarcinoma) and DLD-1 (colorectal adenocarcinoma) cell lines.

Methods: This study examined the antioxidant activities (25-200 $\mu \mathrm{M}$ ) of sulfur-containing glycine imine derivatives via the DPPH, metal chelating and reduction methods. Furthermore the cytotoxic activity of MCF-7, MCF-12A (normal breast epithelial) and DLD-1, CCD-18CO (normal colon fibroblast) were examined with MTT (3-(4,5-Dimethylthiazol-2-yl)-2,5-Diphenyltetrazolium Bromide) and RTCA (Real-time Cell Analysis) assays.

Results: The antioxidant assay of the metal chelating activity showed significant results $(71,77$ and $40 \%$ respectively) as compared to knowing synthetic antioxidant (trolox; 95.45, EDTA; $97.06 \%$ ). Reducing activity was found to be very low compared to the standard

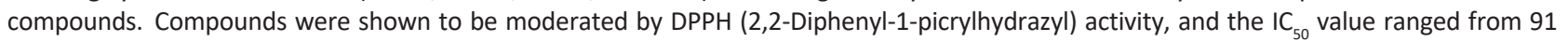
to 150 . The $\mathrm{IC}_{50}$ values $(100 \mu \mathrm{M})$ of the MTT and RTCA analyses were similar.

Conclusion: The study showed that the compounds had selective and significant antioxidant activities, and we also found that they had cytotoxic effects on MCF-7 and DLD-1 cells.

Keywords: Sulfur, Glycine Imine, MTT, RTCA, DPPH, Metal chelating

\section{INTRODUCTION}

According to the World Health Organization the most common types of carcinoma are breast, colon, prostate and lung cancer $(1,2)$. Breast cancer, which is a critical health problem worldwide, is the most common type of cancer among women and the deadliest cancer after lung cancer (3). The cancer with the third highest mortality rate and fourth highest incidence worldwide is cancer of the colon (4). Colorectal cancer accounts for approximately $10 \%$ of cancers in men and women (5).

Human life often involves disease, stressand various other difficulties. In order to protect ourselves against diseases and boost our immune systems, it is necessary for us to take supplemental foods in addition to the basic nourishment required to sustain life. Such protective or inhibitory compounds are called antioxidants. Antioxidants are substances that can suppress or reduce oxidative damage at low concentrations. For many years, antioxidants have been critical in pharmacological studies (6).
Free radicals and oxidants are produced physiologically and metabolically, and play a role in the human body's defence mechanism. These mechanisms depend on cell and tissue type and act antagonistically or synergistically. When produced in large quantities, they can seriously disrupt the structure of biological substrates such as proteins, lipids, lipoproteins and deoxyribonucleic acid (DNA). They have many different potential effects on cells and they easily emerge as anti-cancer. They have an effect on the cell cycle. As a result of this, they prevent cell deathin aging, apoptosis and necrosis and change the anti-cancer mechanism. They cause increased proliferation, angiogenesis and metastasis and suppression of apoptosis. When ROS (reactive oxygen species) increases in concentration, it has a toxic effect and causes chronic diseases. It has been stated that oxidative damage can be prevented by antioxidants in the cell, possibly at low concentrations (7). 
Glutathione (GSH), consisting of glutamic acid, cysteine and glycine, is an antioxidant tripeptide with a reducing form in the cell (8). High oxidative stress and low antioxidant capacity have relationship with glutathione antioxidant systems (9). An important function of glycine is also partially to prevent the antioxidant capacity, and to reduce the oxidative stress which occurs in heavy metals, peroxide or other medicinal toxins (10). Glycine imines with biologically significant activity are also relatively antidiabetic (11).

Glycine suppresses the formation of angiogenesis signals and the growth of tumor cells in endothelial cells. Glycine is seen as a promising addition to targeted cancer treatments used as a standard (12).

Sulfur is a major constituent of biological systems. This element is ordinarily integrated into proteins as a redox active cysteine residue. It is found in the structure of vital antioxidant molecules and glutathione, thioredoxin and glutaredoxin, which are necessary for life. Sulfur exists in all living cells and is a valuable component of many proteins necessary for a healthy life (13).

Many researchers have reported that glycine is protective against hepatotoxicity and nephrotoxicity caused by anoxia, ischemia and various xenobiotics $(10,14)$.

MSM (Methylsulfonethane) is a sulfur-containing organic compound known to have no toxic properties. MSM has been shown to significantly reduce cell viability in human breast cancer cells (15). Cases have been reported where proliferation in various cancer cells was suppressed in treatments with natural sulfur (16). It has also been reported for the first time that cell proliferation was inhibited by an inorganic sulfur in a study on breast cancer (17).

Here, we report the design and testing of the bis(alkylthio) imines, which are key compounds, used for the antioxidant (18) and anti-lipid peroxidation system (19).

Our total synthesis of (Figure 1) began with the preparation of glycine ethyl ester, the key amino acid fragments required for the synthesis of bis-sulfur substituted glycine ethyl ester via the known procedure $(18,19)$.

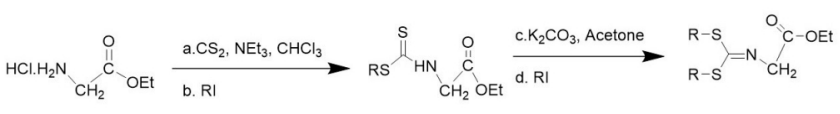

$$
\begin{aligned}
& \text { R: } \operatorname{Pr}(\mathbf{1}), \mathrm{Et}(\mathbf{2}), \mathrm{Me}(\mathbf{3})
\end{aligned}
$$

Figure 1. Synthesis of ethyl 2-((bis(alkylthio)methylene)amino) acetate

In this study, the antioxidant activities (25-200 $\mu \mathrm{M})$ of the sulfur-alkyl side chains in glycine imine derivatives were determined via the free radical scavenging, reducing and metal chelating methods.

In addition, the cytotoxic activity of MCF-7, MCF-12A and DLD-1, CCD-18CO was examined by MTT and RTCA assays with varying concentrations $(25-100 \mu \mathrm{M})$ of compounds for 24hr. The significance of differences between the data sets in the MTT assay was analyzed statistically by ANOVA for four cell lines using the SPSS 20.0 program.

\section{METHODS}

\subsection{Chemistry}

All commercial reagents and solvents were purified by standard procedures prior to use. The silica gel (100-200 Mesh) used for column chromatography were supplied and thin layer chromatography used for Merck silica gel 60 F254 precoated plates $(0.25 \mathrm{~mm})$. The ${ }^{1} \mathrm{H}$ and ${ }^{13} \mathrm{C}-\mathrm{NMR}$ chemical shifts were measured relative to $\mathrm{CDCl}_{3}$ on a BrukerSpectrospin, Avance spectrometer. Mass spectrums were taken Agilent 7890-GCMS and the mass spectra showed the expected molecular ion peaks.Compounds I, II and III were prepared by known methods (20).

General Synthesis Procedure: Glycine ethyl ester hydrochloride $(6 \mathrm{mmol})$ and carbon disulphide $(6.2 \mathrm{mmol})$ in chloroform $(50 \mathrm{~mL})$ were mixed before triethylamine $(12.4$ $\mathrm{mmol}$ ) was added dropwise at room temperature. After $1 \mathrm{~h}$ alkyl iodine $(7 \mathrm{mmol})$ was added, and then the solution was refluxed. After the reaction was completed, first it was extracted with water twice $(30 \mathrm{~mL})$, and secondly with ether and water. The residue was dissolved in acetone $(20 \mathrm{~mL})$ and alkyl iodine $(6 \mathrm{mmol})$, then potassium carbonate $(7 \mathrm{mmol})$ was added. The reaction solution was refluxed for $1 \mathrm{~h}$. The reaction mixture was extracted and residue was evaporated to obtain a light-yellow oil.

Compound I: yield 75\%; oil; selected NMR values ${ }^{1} \mathrm{H}$ NMR $\left(250 \mathrm{~Hz}, \mathrm{CDCl}_{3}\right) 2.78,2.82\left(\mathrm{~s}, 6 \mathrm{H} ;-\mathrm{SCH}_{3}\right), 4.33(\mathrm{t}, \mathrm{J} 7.4 \mathrm{~Hz}, 2 \mathrm{H}$, - $\mathrm{OCH}_{2}$ ) ppm.Compound II: yield 68\%; oil; selected NMR values ${ }^{1} \mathrm{H}$ NMR $\left(250 \mathrm{~Hz}, \mathrm{CDCl}_{3}\right) 3.35-3.48\left(\mathrm{~m}, 4 \mathrm{H},-\mathrm{SCH}_{2}\right), 4.25$ (t, J $7.4 \mathrm{~Hz}, 2 \mathrm{H},-\mathrm{OCH}_{2}$ ) ppm.Compound III: yield 70\%; oil; selected NMR values ${ }^{1} \mathrm{H}$ NMR $\left(250 \mathrm{~Hz}, \mathrm{CDCl}_{3}\right)$ 3.37-3.51 (m, $\left.4 \mathrm{H},-\mathrm{SCH}_{2}\right), 4.00-4.12\left(\mathrm{~m}, 2 \mathrm{H},-\mathrm{OCH}_{2}\right)$ ppm.)

\subsection{Antioxidant Activity}

Doses of the compounds were studied at concentrations of $25,50,100,150$ and $200 \mu \mathrm{M}$. In addition, the antioxidant activity of the compounds was determined using free radical scavenging (21), metal chelating (22), and reducing (23).

\subsubsection{Free Radical Scavenging (DPPH) Activity Assay}

The free radical scavenging activity assay was performed according to (21). Three replicates of the compounds with different concentrations were studied. Butylated hydroxytoluene (BHT), Trolox and Butylated hydroxyanisole (BHA) $(25-200 \mu \mathrm{g} / \mathrm{mL})$ were used as standard. The activities of the compounds at $517 \mathrm{~nm}$ absorbance were measured. The free radical scavenging activity $(\%)=\left[\left(A_{0}-A_{1}\right) / A_{0}\right] \times 100 .\left(A_{0}\right.$ $=$ control absorbance and $A_{1}=$ sample solution absorbance). 


\subsubsection{Metal Chelating Activity (Fe ${ }^{+2}$ lons Chelating Activity) Assay}

The chelate activity assay of the compounds was performed according to (22). Butylated hydroxytoluene (BHT), Trolox and Ethylenediaminetetraacetic acid (EDTA) $(25-200 \mu \mathrm{g} / \mathrm{mL})$ were used as standard. The activities of the compounds at $562 \mathrm{~nm}$ absorbance were measured. The metal chelating activity $(\%)=\left[\left(A_{0}-A_{1}\right) / A_{0}\right] \times 100 .\left(A_{0}=\right.$ control absorbance and $A_{1}=$ sample solution absorbance).

\subsubsection{Reducing Activity Assay}

The reducing activity of the compounds was performed according to (23). EDTA, Trolox and Gallic were used as standard $(25-200 \mu \mathrm{g} / \mathrm{mL})$. The activities of the compounds at $700 \mathrm{~nm}$ absorbance were measured and activity results were evaluated by absorbance measurements.

\subsection{Cytotoxic Activity}

\subsubsection{Cell Lines}

In in vitro cell culture studies MCF-7 (ATCC ${ }^{\circledR} \mathrm{HTB}^{\mathrm{T}} 2^{\mathrm{TM}}$ ) (human breast adenocarcinoma), MCF-12A (ATCC ${ }^{\circledR}$ CRL-10782 ${ }^{\text {TM }}$ ) (normal breast epithelium), DLD-1 (colon cancer) (ATCC ${ }^{\circledR}$ $\mathrm{CCL}_{22}{ }^{\mathrm{TM}}$ ) and CCD-18CO (normal colon epithelium) (ATCC ${ }^{\circledR}$ CRL-1459 ${ }^{\mathrm{TM}}$ ) cell lines were used. Cancer cell lines indicated with ATCC numbers were obtained from the cell culture collection at Gebze Technical University. The study did not include human subjects, and ethics committee approval was therefore not required.

\subsubsection{Cell Culture}

In the study, MCF-7, MCF-12A, DLD-1 and CCD-18CO cell lines DMEM (Dulbecco's Modified Eagle Environment), EMEM (Eagle's Minimum Essential Medium) and RPMI-1640 (Roswell Park Memorial Institute) mediums containing $10 \%$ fetal bovine serum (FBS) and/or horse serum were cultured with a $5 \% \mathrm{CO}_{2}$ incubator. These were produced by incubation for 24 hours. Cells were grown to $80 \%$ saturation, followed by washing with phosphate buffered saline (PBS). 1X TrypsinEDTA was used to pass the cells (24).

\subsubsection{MTT Assay}

MTT analysis is a method in which cell proliferation is determined based on the colorimetric measurement of color change occurring in cells incubated with enzymatic activity due to formazan dyes or MTT reduction. The cytotoxic or proliferative effects of any therapeutic agent to be used on this cell can be determined by this method.

The analysis of the possible cytotoxic effect of the sulfurcontaining glycine imine derivatives compounds on MCF7, MCF-12A, DLD-1 and CCD-18CO cell lines was performed according to the manufacturer's instructions for use with the MTT (Sigma). The resulting color change is caused by the reduction of the tetrazolium salt in activated cell mitochondria of yellow-colored formazan salts. The absorbance value of these compounds is proportional to the metabolic activity.

$100 \mu$ l of RPMI medium was prepared in a 96 -well plate $\left(1 \times 10^{4}\right.$ / well) 1 day before the MTT assay was applied and the wells were cultured. The microplate was kept in an incubator at $37{ }^{\circ} \mathrm{C}$ and $5 \% \mathrm{CO}_{2}$ for $24 \mathrm{~h}$ to allow the cells to adhere to the surface. Sulfur-containing glycine imine derivatives compounds prepared in serial dilutions (1.56-3.12-6.25-12.5-25-100 $\mu \mathrm{M})$ were added to the wells after $24 \mathrm{~h}$ of incubation. After incubation, $100 \mu$ l of MTT ( $5 \mathrm{mg} / \mathrm{mL}$ ) solution was added to the cells for $2 \mathrm{~h}$ and then $100 \mu \mathrm{L}$ of DMSO (dimethyl sulfoxide) was added to the wells to terminate the reaction. Incubated cells, microplate reader spectrophotometer and $570 \mathrm{~nm}$ absorbance value measurements were taken in three replicates. The dose and $\%$ cell viability curve were determined with the help of the Microsoft Excel program and 50\% suppressive concentration $\left(\mathrm{IC}_{50}\right)$ was calculated by logarithmic slope graph (Cytotoxicity = test absorbance value / control absorbance average value $x$ 100). Experiments were repeated three times for each compound concentration and solution. According to these results, the cytotoxic effects of sulfur-containing glycine imine derivatives compounds in cell lines were evaluated and the dose-response relationship was defined (25).

\section{Statistics}

The significance of the differences between the data for the MCF-7 and MCF-12A, DLD-1 and CCD-18CO cell lines was analyzed statistically with ANOVA using SPSS 20.0 program. The conclusions were indicated as ID50 \pm SE (standard error of the mean) for cell lines.

\subsubsection{Real-Time Cell Analyzer (iCELLigence) Assay}

The study used MCF-7, MCF-12A, DLD-1 and CCD-18CO cells. The mediums of DMEM, EMEM and RPMI-1640 were incubated at $37{ }^{\circ} \mathrm{C}$ and $5 \% \mathrm{CO}_{2} .10 \% \mathrm{FBS}$ and/or horse serum was added to the media. $1 \times 10^{4}$ cells / $400 \mu \mathrm{L}$ medium were loaded into the E-plates of the iCELLigence RTCA device. Cells were left to adhere to the E-plates for 24 hours, 25-50$100 \mu \mathrm{M}$ concentrations of the compounds were added to the E-plates at the end of 24 hours and monitored in real time for 24 hours. The viability of the cells was calculated by comparing the $25-50-100 \mu \mathrm{M}$ concentrations of the compounds according to the negative control (26).

\section{RESULTS}

\subsection{Chemistry}

The three bis(alkylthio)imines, ethyl 2-((bis(methylthio) methylene)amino)acetate, ethyl 2-((bis(ethylthio)methylene) amino)acetate, and ethyl 2 ((bis(propylthio)methylene) amino)acetate, which were given the names I, II, and III respectively. were synthesized according to the methods found in the literature $(18,19)$. 


\subsection{Antioxidant Activity}

The DPPH activity III > II > I and the metal chelating activity II , I , III were determined. The reductive activity results were found to be very low compared to standard compounds. The $\mathrm{IC}_{50}$ value is defined as the half inhibition concentration in inhibiting antioxidant activity. Antioxidant activities have an $\mathrm{IC}_{50}$ value of 91 to 150 (Table 1-3) (Figure 2-4).

Table 1. DPPH activity (free radical scavenging) and $I C_{50}$ of compounds I, II and III

\begin{tabular}{ccccccc} 
Compounds & \multicolumn{7}{c}{ Concentration $(\boldsymbol{\mu M})$} \\
\cline { 2 - 6 } & $\mathbf{2 5}$ & $\mathbf{5 0}$ & $\mathbf{1 0 0}$ & $\mathbf{1 5 0}$ & $\mathbf{2 0 0}$ & IC $_{50}$ \\
\hline I & 36.727 & 41.467 & 44.495 & 51.376 & 53.975 & 150.01 \\
\hline II & 29.969 & 51.834 & 53.975 & 61.071 & 63.761 & 91.733 \\
\hline III & 7.4159 & 46.116 & 63.180 & 68.455 & 78.746 & 96.986 \\
\hline BHT & 61.840 & 74.570 & 78.360 & 85.620 & 94.690 & \\
\cline { 1 - 6 } Trolox & 59.590 & 70.520 & 72.540 & 81.360 & 90.570 & \\
\cline { 1 - 5 } BHA & 50.450 & 53.970 & 60.990 & 76.430 & 82.470 & \\
\hline
\end{tabular}

Table 2. Chelating activity of Metal (Fe ${ }^{2+}$ ions chelating activity) of compounds I, II and III

\begin{tabular}{cccccc}
\multirow{2}{*}{ Compounds } & \multicolumn{6}{c}{ Concentration $(\boldsymbol{\mu M})$} \\
\cline { 2 - 6 } & $\mathbf{2 5}$ & $\mathbf{5 0}$ & $\mathbf{1 0 0}$ & $\mathbf{1 5 0}$ & $\mathbf{2 0 0}$ \\
\hline I & 42.933 & 53.069 & 62.961 & 67.567 & 71.662 \\
\hline II & 12.043 & 31.603 & 42.311 & 56.298 & 77.356 \\
\hline III & 17.198 & 26.615 & 29.500 & 33.956 & 40.388 \\
\hline BHT & 77.000 & 81.250 & 83.090 & 94.200 & 97.500 \\
\hline Trolox & 54.270 & 67.840 & 74.250 & 81.530 & 95.450 \\
\hline EDTA & 70.850 & 72.320 & 79.470 & 81.090 & 97.060 \\
\hline
\end{tabular}

Table 3. Reducing activity of compounds I, II and III

\begin{tabular}{cccccc} 
Compounds & $\mathbf{5}$ Concentration $(\boldsymbol{\mu M})$ \\
\cline { 2 - 6 } & $\mathbf{2 5}$ & $\mathbf{5 0}$ & $\mathbf{1 0 0}$ & $\mathbf{1 5 0}$ & $\mathbf{2 0 0}$ \\
\hline I & 0.050 & 0.080 & 0.104 & 0.113 & 0.123 \\
\hline II & 0.137 & 0.155 & 0.213 & 0.212 & 0.238 \\
\hline III & 0.168 & 0.216 & 0.274 & 0.267 & 0.317 \\
\hline EDTA & 2.178 & 1.503 & 3.865 & 3.925 & 4.355 \\
\hline Trolox & 1.506 & 2.765 & 2.537 & 3.689 & 2.701 \\
\hline GALLiC & 1.273 & 1.511 & 1.876 & 3.597 & 3.756 \\
\hline
\end{tabular}

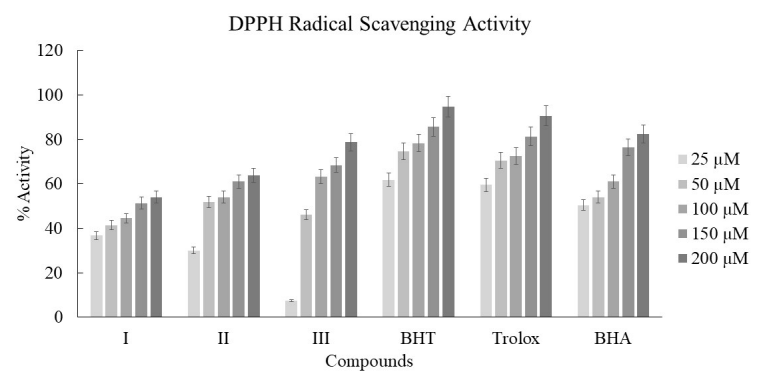

Figure 2. DPPH activities of compounds and BHT, Trolox and BHA as standards

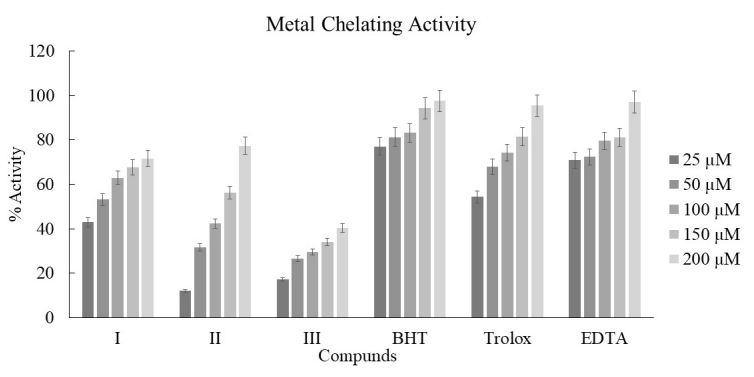

Figure 3. Metal activity of compounds and BHT, Trolox and EDTA as standards

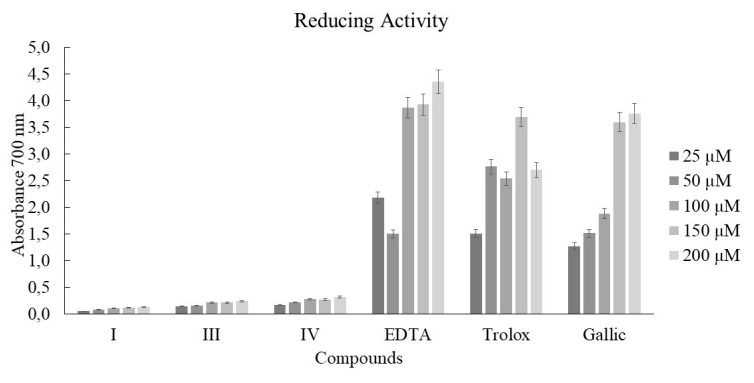

Figure 4. Reducing activities of compounds and EDTA Trolox and Gallic as standards

\subsection{Cytotoxic Activity}

Three compounds were investigated by comparison of two normal and two cancer cell lines. Compounds were evaluated for their cytotoxic effects against MCF-7, DLD-1 cancer cell lines and MCF-12A, CCD-18CO normal cell lines. For this purpose, cells were cultured with compounds (I-II-III) at $37^{\circ} \mathrm{C}$ for $24 \mathrm{~h}$ at concentrations of $25,50,100 \mu \mathrm{M}$ (the best doses obtained in MTT assays). Cell viability was measured at $570 \mathrm{~nm}$, the optical density (OD) value. Cytotoxic activity was calculated using the formula $(\%)=$ (average experimental OD value / average control OD value) $\times 100 \%$. Values were stated as $50 \%$ inhibitory concentration $\left(\mathrm{IC}_{50}\right)$. The compounds synthesized in the study are particularly noteworthy as anticancer agents.

Based on the MTT assay the cytotoxic activities of the compounds for MCF-7 cell line were determined as II > III > I. The cytotoxic activities of the compounds for DLD-1 cell line were determined as II > I > III. In fact, the cytotoxic activity of the compounds I and III were approximately the same (Figure 5 and 6).

Based on the RTCA assay the cytotoxic activities of the compounds for MCF-7 cell line were determined as II , III , I. The cytotoxic activities of the compounds for DLD-1 cell line were determined as II > III > I. It can even be said that compound I did not affect cell proliferation (Figure 7 and 8). 

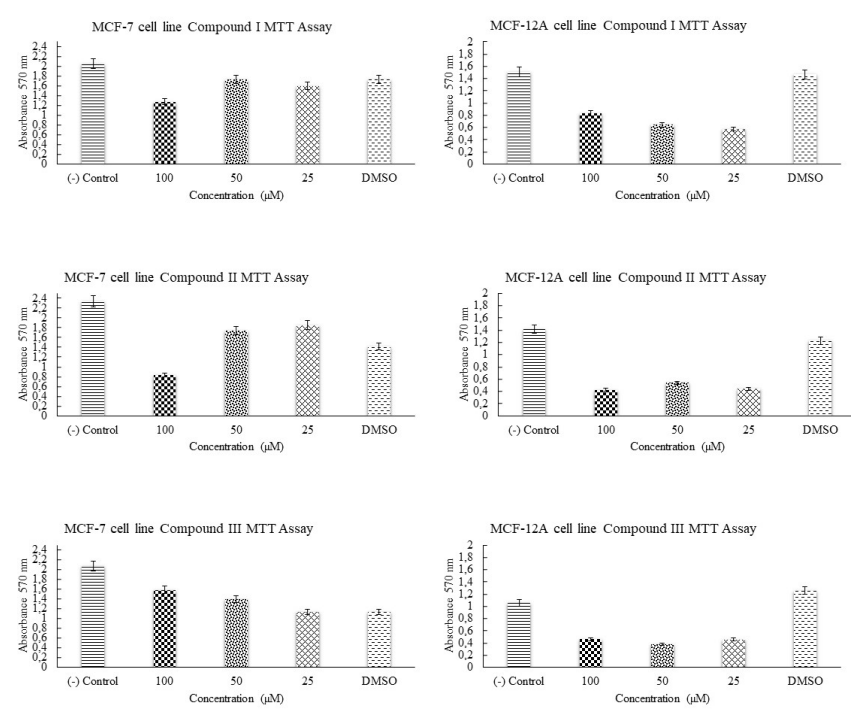

Figure 5. MTT assay of increasing concentrations of compounds on MCF-7 and MCF-12A cells.
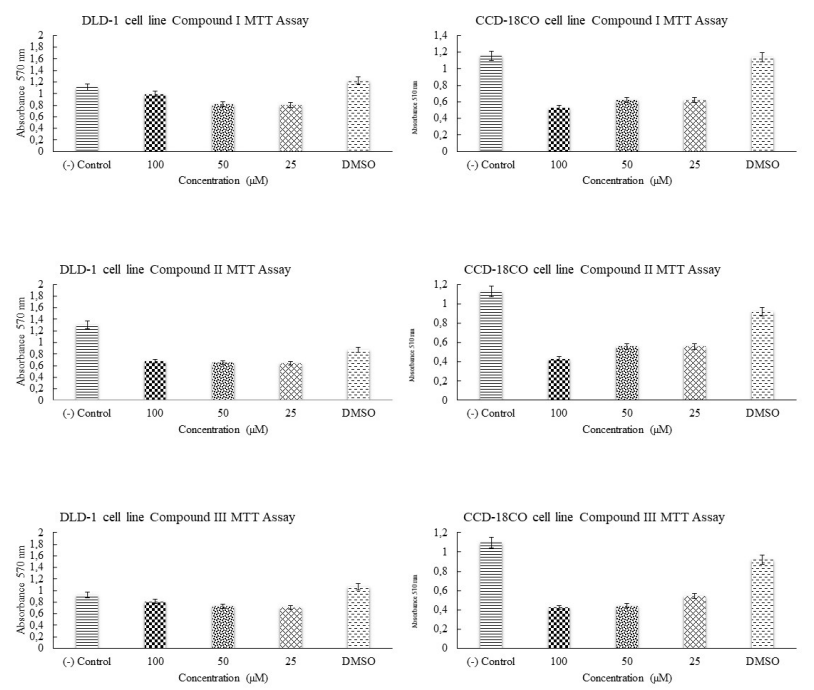

Figure 6. MTT assay of increasing concentrations of compounds on DLD-1 and CCD-18CO cells.

Compound II exhibited IC ${ }_{50}$ values approximately better than compound I and III under the same conditions, indicating improved selectivity for cancer cells.

Also, MCF-12A and CCD-18CO were found to affect cell proliferation and reduce cell proliferation in normal cell lines. Compounds I, II and III exhibited moderate cytotoxicity toward the normal cell lines.

In addition, cytotoxic activities (MTT and RTCA assays) of sulfur-containing glycine imine derivatives were compared with antioxidant activities, and the cytotoxic activities were found to be similar to the antioxidant activity results.
The MTT assay concentrations of compounds I, II and III in four cell lines were compared. As a result of ANOVA analyses (SPSS 20.0), there was a significant difference between the compounds and concentrations. Post hoc analyzes were done to understand the relationships between the groups. First, the homogeneity of the variance test result was examined and tests were applied depending on these results. GamesHowell and Tukey tests were used for multiple comparisons of compounds I, II and III in MCF-7 and MCF-12A, DLD-1 and CCD-18CO cell lines ( $p<0.005$ ) (Table 4 and 5) (Figure 9 and 10). 

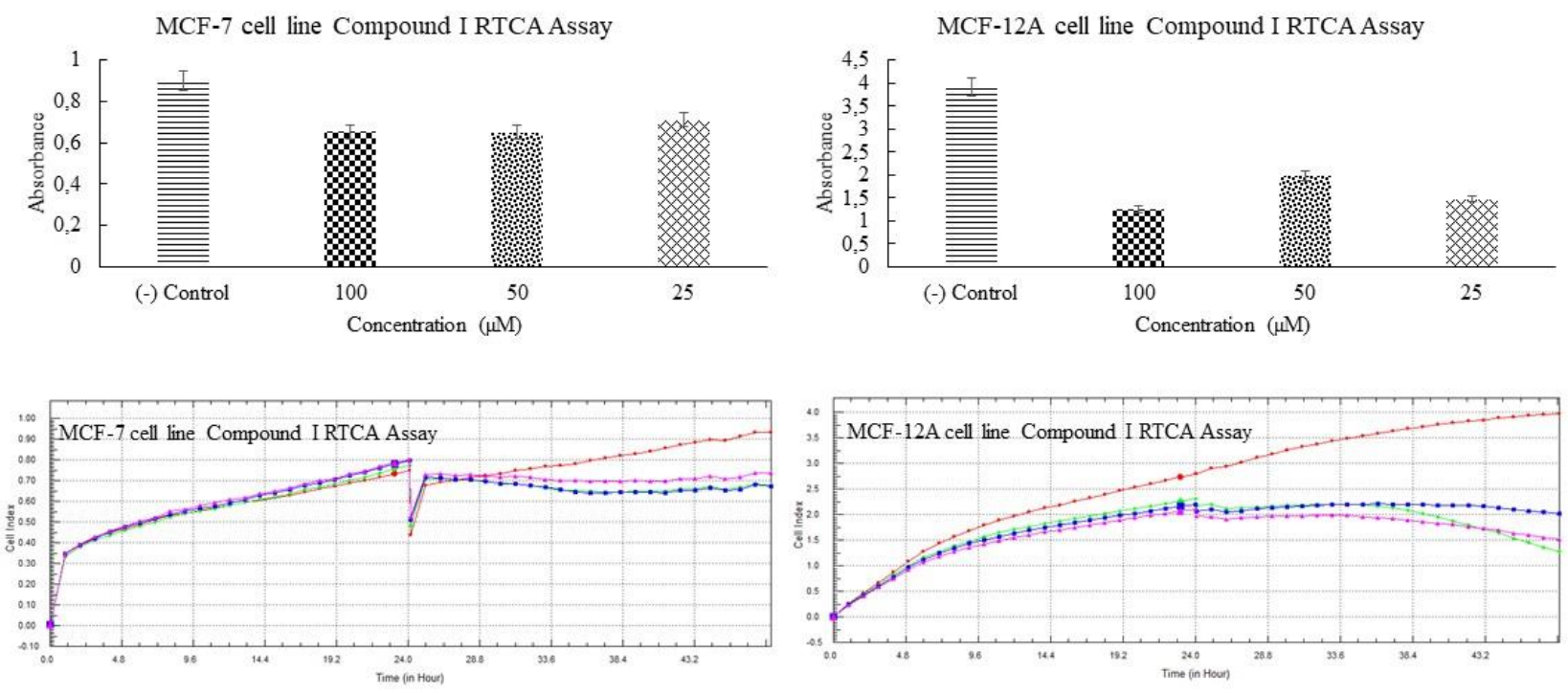

MCF-7 cell line Compound II RTCA Assay
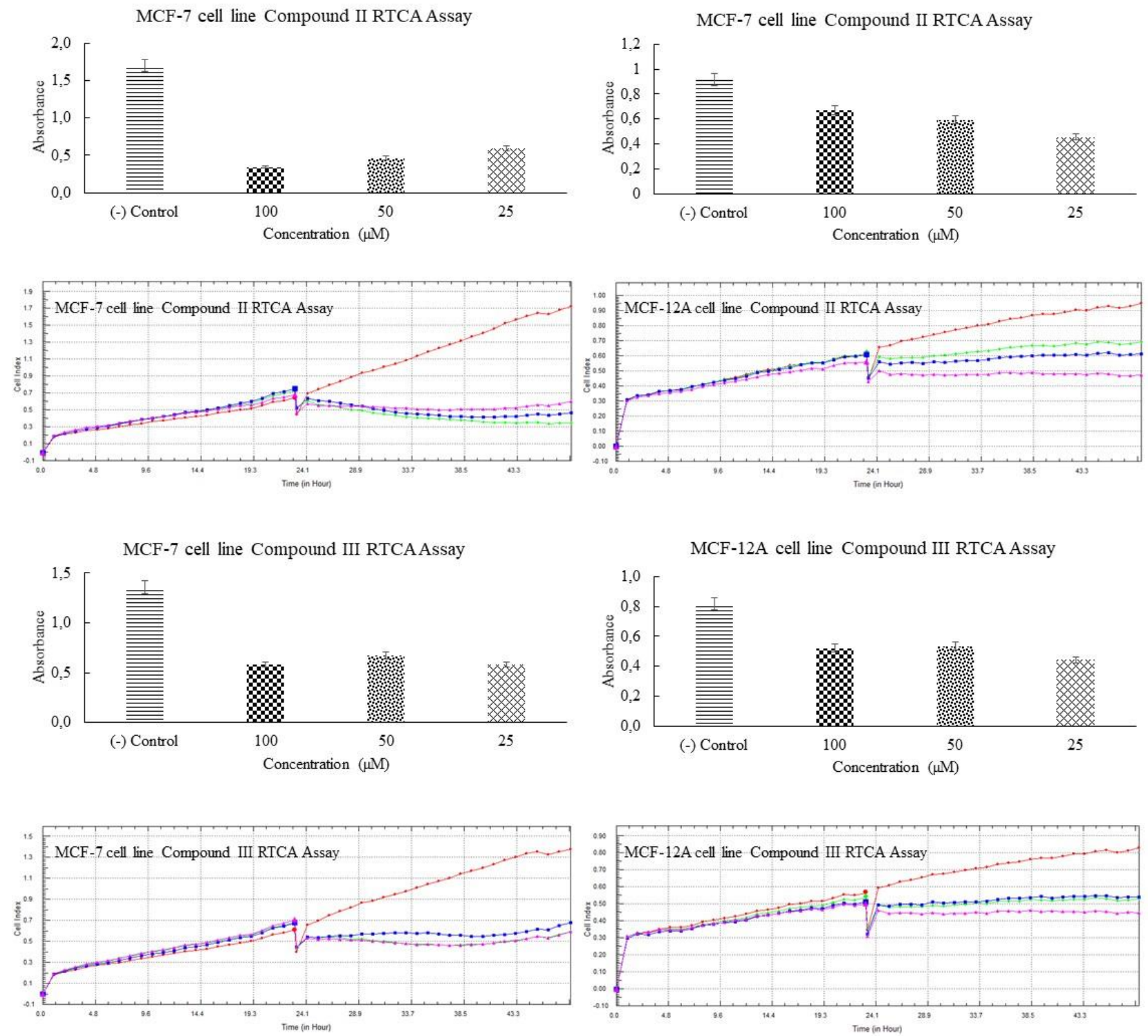

Figure 7. Real-time cell analysis of increasing concentrations of compounds on MCF-7 and MCF-12A cells. (Red; Negative control, Green; 100 $\mu M$, Blue; $50 \mu M$, Pink; $25 \mu M$ ). 

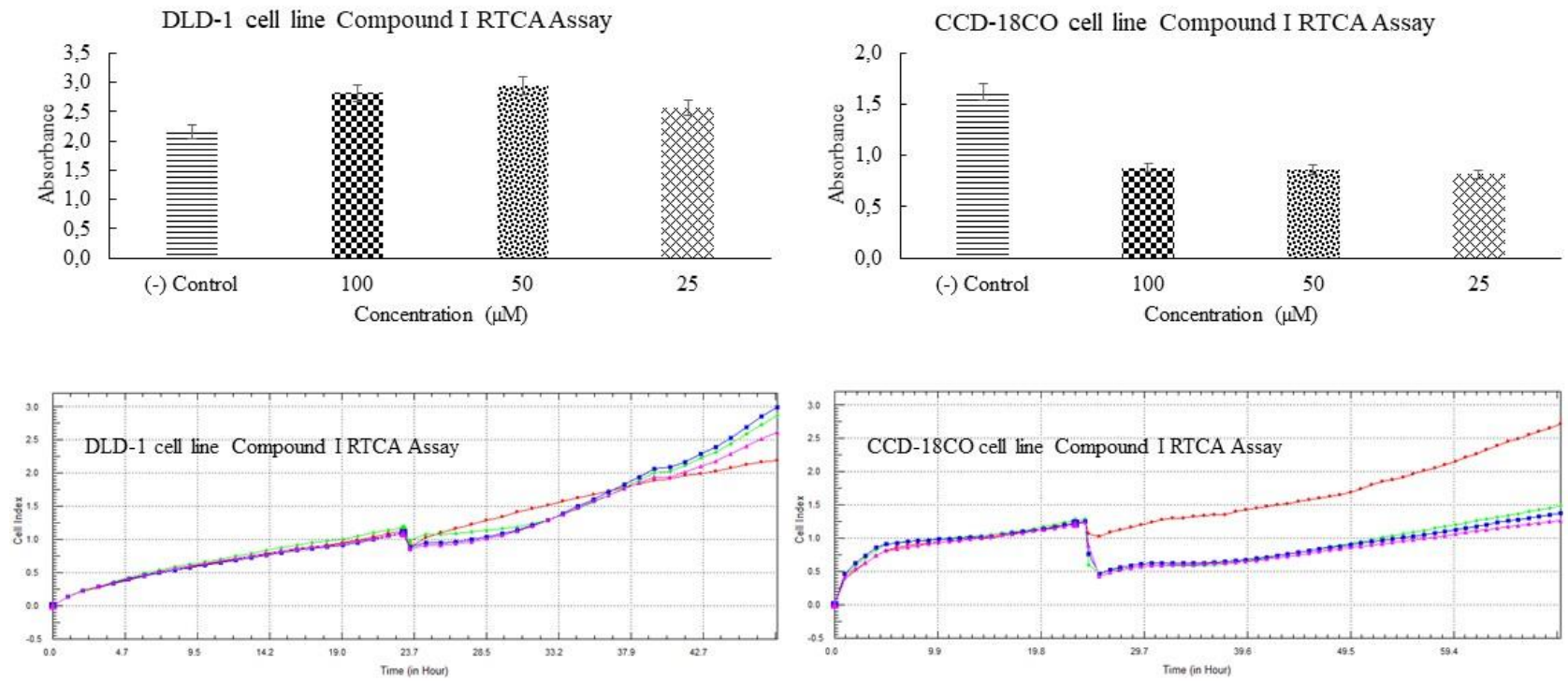

DLD-1 cell line Compound II RTCA Assay
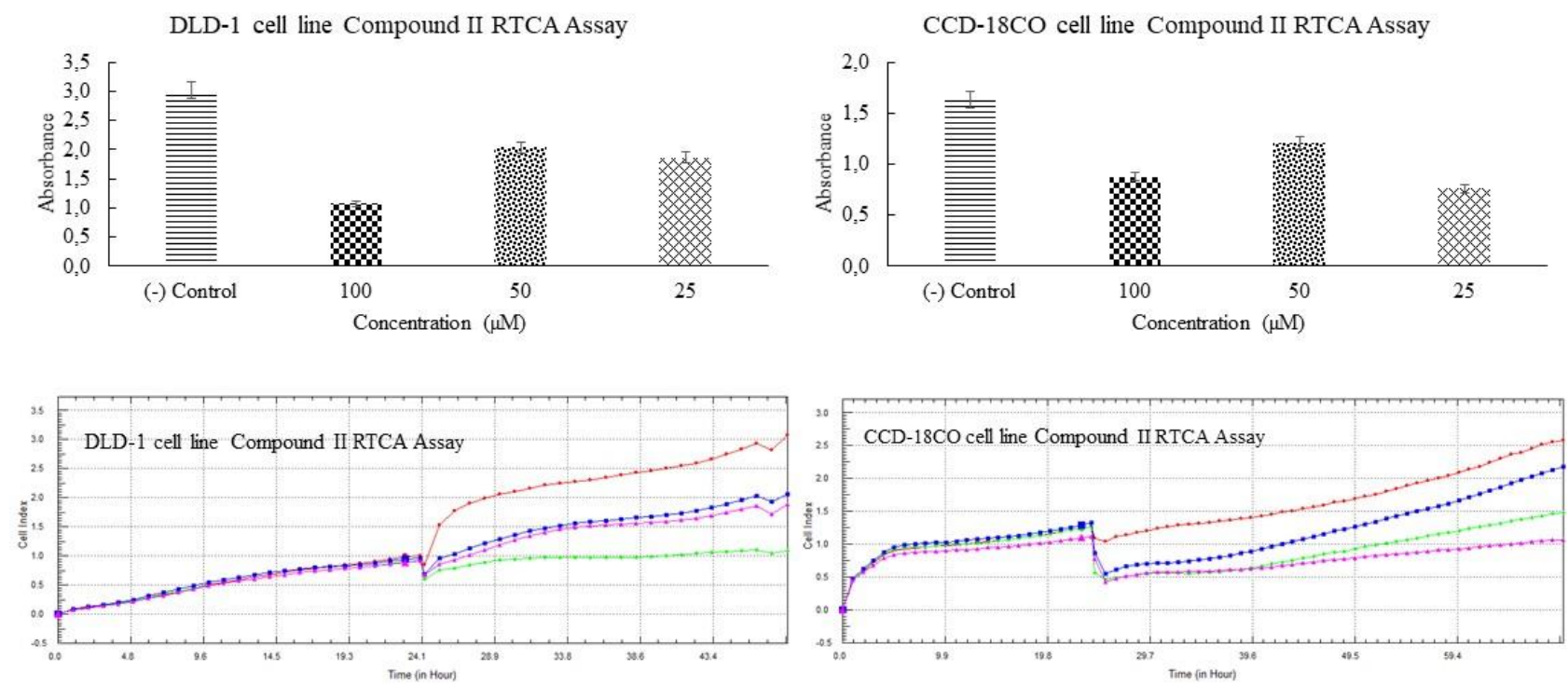

DLD-1 cell line Compound III RTCA Assay

CCD-18CO cell line Compound III RTCAAssay
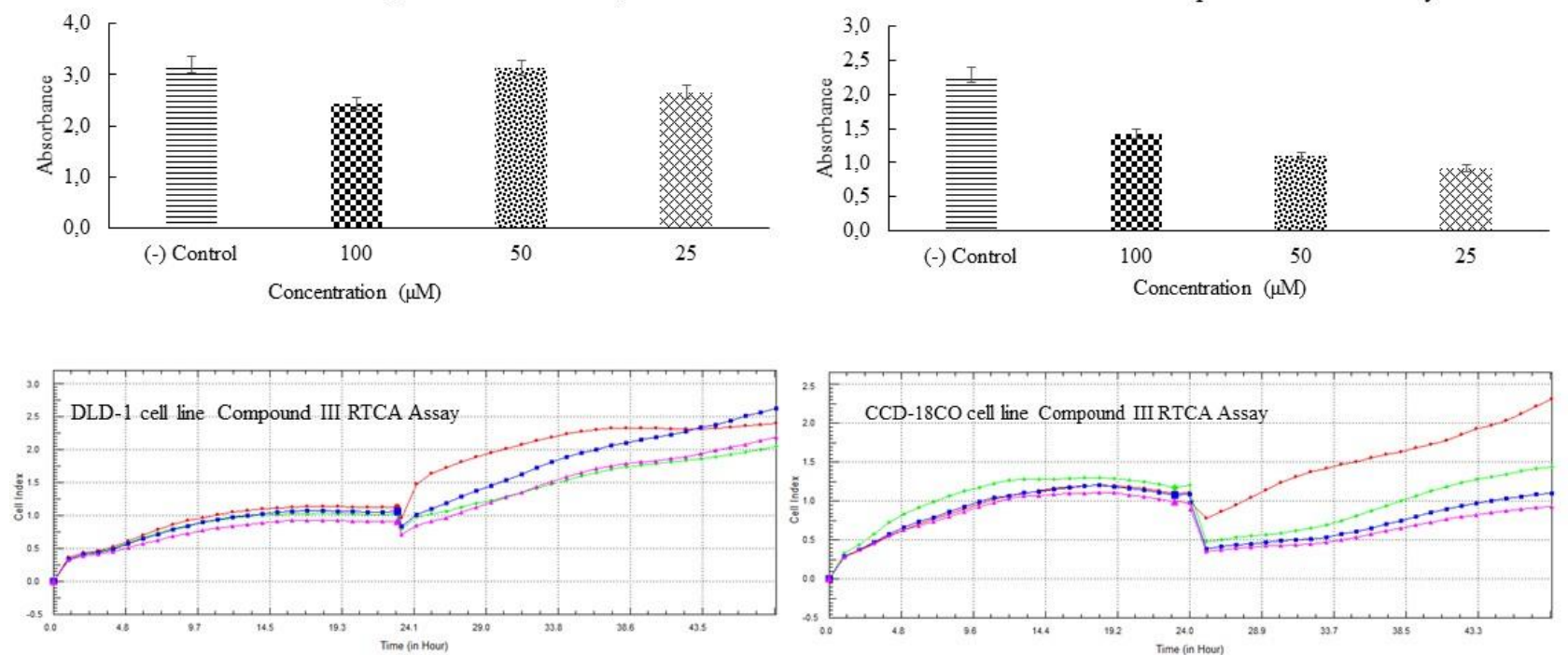

Figure 8. Real-time cell analysis of increasing concentrations of compounds on DLD-1 and CCD-18CO cells. (Red; Negative control, Green; 100 $\mu \mathrm{M}$, Blue; $50 \mu \mathrm{M}$, Pink; $25 \mu \mathrm{M})$. 

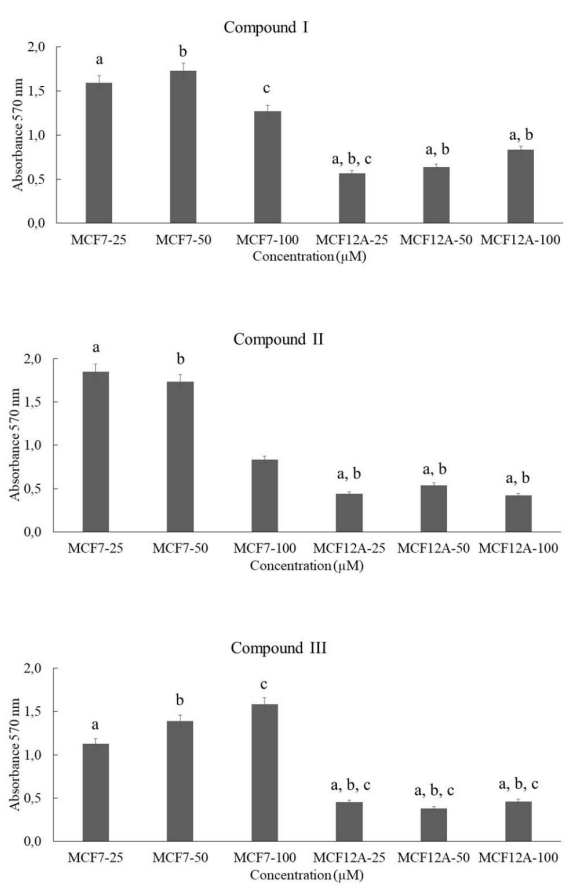

Figure 9. Comparison between MCF-7 and MCF-12A cell lines in terms of cell viability. $a, b, c$ indicate significant difference for compounds
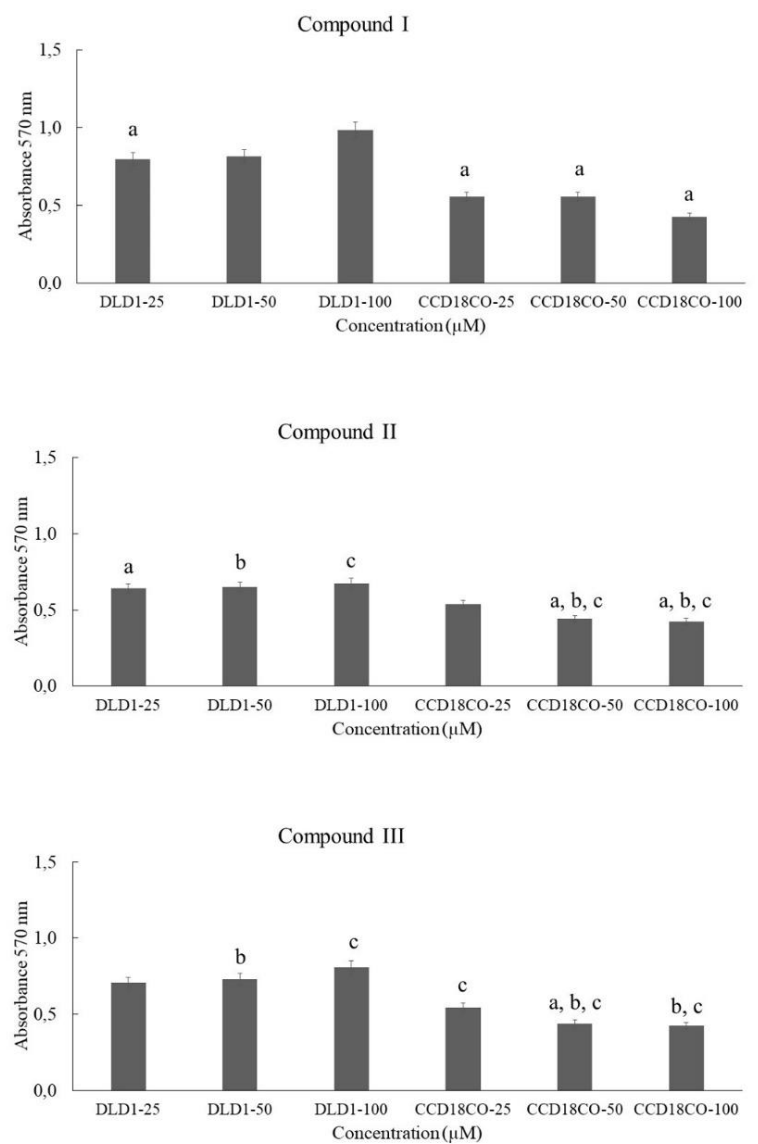

Figure 10. Comparison between DLD-1 and CCD-18CO cell lines in terms of cell viability. $a, b, c$ indicate significant difference for compounds
Table 4. In vitro cell viability of the cell lines were investigated by MTT assay after treating MCF-7 and MCF-12A cell lines with varying concentrations of compounds for $24 \mathrm{hr}$. The acquired data were evaluated using SPSS 20.0 analysis and defined as $I C_{50}$ values.

\begin{tabular}{cccc} 
Compounds & $\begin{array}{c}\text { Concentration } \\
(\mu \mathrm{M})\end{array}$ & \multicolumn{2}{c}{ Cell lines ID50 $[\mu \mathrm{m}] \pm$ SE } \\
\cline { 2 - 4 } & 25 & $1.592 \pm 0.143$ & $0.568 \pm 0.095$ \\
\cline { 2 - 4 } I & 50 & $1.731 \pm 0.123$ & $0.64 \pm 0.058$ \\
\cline { 2 - 4 } & 100 & $1.272 \pm 0.255$ & $0.832 \pm 0.129$ \\
\hline \multirow{3}{*}{ II } & 25 & $1.848 \pm 0.243$ & $0.439 \pm 0.014$ \\
& 50 & $1.733 \pm 0.040$ & $0.539 \pm 0.025$ \\
\hline & 100 & $0.835 \pm 0.046$ & $0.424 \pm 0.008$ \\
\hline III & 25 & $1.130 \pm 0.179$ & $0.454 \pm 0.015$ \\
\cline { 2 - 4 } & 50 & $1.391 \pm 0.202$ & $0.381 \pm 0.010$ \\
\hline & 100 & $1.583 \pm 0.214$ & $0.462 \pm 0.018$ \\
\hline
\end{tabular}

Table 5. In vitro cell viability of the cell lines were investigated by MTT assay after treating DLD-1 and CCD-18CO cell lines with varying concentrations of compounds for $24 \mathrm{hr}$. The acquired data were evaluated using SPSS 20.0 analysis and defined as $I C_{50}$ values.

\begin{tabular}{cccc}
\multirow{2}{*}{ Compounds } & \multicolumn{2}{c}{ Concentration $(\mu \mathrm{M})$} & \multicolumn{2}{c}{ Dell lines ID50 $[\mu \mathrm{m}] \pm$ SE } \\
\cline { 2 - 4 } & 25 & $0.799 \pm 0.022$ & $0.556 \pm 0.037$ \\
\cline { 2 - 4 } I & 50 & $0.816 \pm 0.096$ & $0.556 \pm 0.029$ \\
\cline { 2 - 4 } & 100 & $0.985 \pm 0.075$ & $0.427 \pm 0.004$ \\
\hline \multirow{2}{*}{ II } & 25 & $0.641 \pm 0.057$ & $0.537 \pm 0.008$ \\
\hline & 50 & $0.649 \pm 0.065$ & $0.441 \pm 0.006$ \\
\hline \multirow{2}{*}{ III } & 100 & $0.673 \pm 0.039$ & $0.423 \pm 0.003$ \\
\hline & 25 & $0.706 \pm 0.076$ & $0.544 \pm 0.003$ \\
\hline & 50 & $0.731 \pm 0.032$ & $0.440 \pm 0.003$ \\
\hline & 100 & $0.809 \pm 0.031$ & $0.423 \pm 0.011$ \\
\hline
\end{tabular}

\section{DISCUSSION}

A study was conducted on the design, characterization and biological activity of the glycine derivatives, and the results showed cytotoxicity to 293T (27). In the current study, three different compounds derived from glycine imine containing sulfur were synthesized. Antioxidant and cytotoxic activity studies of the compounds were designed and carried out using five different methods. The compounds were shown to exhibit high DPPH and Metal chelating activity and high cytotoxic activity in MCF-7 and DLD-1 cells. It has been reported that glycine has protective properties against the state of shock caused by blood loss or endotoxin, reduces alcohol levels in the stomach and provides healing against alcohol-induced hepatitis. It has also been determined that it reverses the liver damage caused by hepatotoxic drugs, suppresses programmed cell death (apoptosis) and reduces the nephrotoxicity caused by the drugs, and prevents hypoxia and the formation of free radicals in the kidney (28). In the current study, three different antioxidant activity studies and two different cytotoxic activity studies were performed using two different cell lines. It was observed that glycine derived compounds exhibit anti-cancer activity in MCF-7 and DLD-1 cells. Apoptotic activity studies of glycine derived compounds are planned as the next step. MSM, a natural compound containing sulfur, has been reported to significantly reduce 
human breast cancer cells (15). In the current study, the anti-tumor effects of the compounds were investigated using breast and colon cancer cells. It was determined that the compounds show high cytotoxic activity in breast and colon cancer cells. It has been reported that many patients with cancer have been given antioxidant supplements during cancer treatment to alleviate toxic effects and that these supplements contribute to an improvement in their condition, even if only to a small extent (29). Given that antioxidant and cytotoxic activity studies form the basis of cancer studies, the original compounds and methods used in this study confirm this purpose.

The information in the literature on synthesized compounds and biological activity studies is limited. Therefore, studies of compounds and activity are rare. The current study shows that sulfur-containing compounds in MCF-7 and DLD-1 cell lines have both antioxidant and cytotoxicity activities. In terms of comparing the compounds' antioxidant and cytotoxic activities, it was found that the compounds gave parallel results. Compound II had prominent selective properties in both the cytotoxic activity studies and the antioxidant studies.

\section{CONCLUSION}

We evaluated the antioxidant activities as DPPH, metal chelating, and cytotoxic activity using the MTT and RTCA methods of methyl, ethyl, propyl analogs of sulfur-containing glycine imine derivatives for describing the effect of a sulfurlinked alkyl group.

As a result of the study, it is thought that compound II has anti-oxidative and cytotoxic properties, preventing cell proliferation and reducing oxidative damage.

It is difficult to find information or studies about sulfurcontaining glycine imine derivatives in the literature. This study is specific both for derivatives of compounds and cancer cells.

We concluded that this new drug candidate could reduce oxidative damage and had an effect on MCF-7 and DLD-1 cancer cells.

\section{REFERENCES}

[1] Jemal A, Siegel R, Ward E, Hao Y. Cancer Statistics, CA. Cancer J Clin. 2008;58(2):71-96.

[2] Siegel RL, Miller KD, Jemal A. Cancer Statistics, CA Cancer J Clin. 2017;67(1):7-30.

[3] World Health Organization. WHO. What is cancer?. https:// www.who.int/cancer/en/ (2018).

[4] Saip P, Keskin S, Özkan M, Kaplan MA, Aydoğan F, Demirağ GG, et al. The Access Rate to Diagnosıs and Treatment Modalıtıes in Breast Cancer Patıents in Turkey; Multıcenter Observatıonal Study. J Breast Health 2011;7:109-117.

[5] Jemal A, Siegel R, Ward E, Hao Y, Xu J, Thu MJ. Cancer statistics, CA. Cancer J Clin 2009; 59:225-49.
[6] Vaya J, Aviram M. Nutritional Antioxidants: Mechanisms of Action, Analyses of Activities and Medical Applications Curr. Med. Chem. - Imm., Endoc. \& Metab. Agents, 2001;1:99-117.

[7] Valadez-Vega C, Delgado-Olivares L, Morales González JA, Alanís García E, Villagomez Ibarra JR, Ramírez Moreno, E., et al. The role of natural antioxidants in cancer disease. En MoralesGonzález JA.(Edi.), Oxidative Stress and Chronic Degenerative Diseases - a Role for Antioxidants. 2013;391-418.

[8] Ganapathy V. Protein digestion and absorption. In Physiology of the Gastrointestinal Tract (Fifth Edition), Chapter 59 Protein Digestion and Absorption, 2012;1595-1623.

[9] Cheng SB, Liu HT, Chen SY, Lin PT, Lai CY.Huang, YC. Changes of oxidative stress, glutathione, and its dependent antioxidant enzyme activities in patients with hepatocellular carcinoma before and after tumor resection. PloS one, 2017;12(1):e0170016.

[10] Deters M, Siegers CP, Strubelt O. Influence of glycine on the damage induced in isolated perfused rat liver by five hepatotoxic agents. Toxicology, 1998;128:63-72.

[11] Vaillancourt VA, Larsen SD, Tanis SP, Burr JE, Connell MA, Cudahy, MM. et al. Synthesis and biological activity of aminoguanidine and diaminoguanidine analogues of the antidiabetic/antiobesity agent 3-guanidinopropionic acid. J Med Chem 2001;44(8):1231-1248.

[12] Bruns H, Kazanavicius D, Schultze D, Saeedi MA. Yamanaka K, Strupas K, et al. Glycine inhibits angiogenesis in colorectal cancer: Role of endothelial cells. Amino Acids, 2016;48: 25492558.

[13] Mukwevho E, Ferreira Z, Ayeleso A. Potential Role of Sulfur-Containing Antioxidant Systems in Highly Oxidative Environments. Molecules, 2014;19:19376-19389.

[14] Santhilkumar R, Sengottuvelan M, Nalini N. Protective effect of glycine supplementation in the levels of lipid peroxidation, and antioxidant enzymes in the erythrocyte of rats with alcohol-induced liver injury. Cell Biochem Funct 2004;22:123128.

[15] Lim E, Hong D, Park J, Joung Y, Darvin P, Kim S, et al. Methylsulfonylmethane Suppresses Breast Cancer Growth by Down-Regulating STAT3 and STAT5b Pathways, PloS one, 2012;7(4): e33361.

[16] Kong CS, Bak SS, Rhee SH, Rho CW, Kim NK. Fermentation properties of young radish Kimchi prepared using young radish cultivated in the soil containing sulfur and it's inhibitory effect on the growth of AGS human gastric adenocarcinoma cells. J Korean Soc Food Sci Nutr 2006;35:158-163.

[17] Ha AW, Hong KH, Kim HS, Kim WK. Inorganic sulfur reduces cell proliferation by inhibiting of ErbB2 and ErbB3 protein and mRNA expression in MDA-MB-231 human breast cancer cells. Nutrit Res Pract 2013;7(2):89-95.

[18] Georgiou D, Toutountzoglou V, Muir KW, Hadjipavlou-Litina $D$, Elemes $Y$. Synthesis of sulfur containing dihydro-pyrrolo derivatives and their biological evaluation as antioxidants. Bio Med Chem 2012;20(17):5103-5109.

[19] Pelit E, Oikonomou K, Gul M, Georgiou D, Szafert S, Katsamakas $S$, Elemes $Y$. $\alpha$-Amination and the 5-exo-trig cyclization reaction of sulfur-containing Schiff bases with $\mathrm{N}$-phenyltriazolinedione and their anti-lipid peroxidation activity. Com Ren Chim 2017;20(4):424-434.

[20] Hoppe D, Beckmann L. Metallierte Stickstoff-Derivate der Kohlensäure in der organischen Synthese, XIII. Selektive Mono- und Dialkylierung von $\mathrm{N}$-[Bis(alkylthio)-methylen]glycin-ethylestern 
zum Aufbau von kettenverlängerten und $\alpha$-verzweigten $\alpha$ Aminosäureestern, Liebigs Ann Chem 1979;2066-2075.

[21] Brand-Williams W, Cuvelier ME, Berset C. Use of a Free Radical Method to Evaluate Antioxidant Activity. LWT-Food Sci Technol 1995;28:25-30.

[22] Decker EA, Welch B. Role of Ferritin as a Lipid Oxidation Catalyst in Muscle Food. J. Agric. Food Chem., 1990;38:674-677.

[23] Oyaizu M. Studies on Product of Browning Reaction Prepared from Glucose Amine. Jpn J Nutr 1986;44:307-315.

[24] Freshney RI. Culture of Animal Cells [6th (sixth) Edition], John Wiley \& Sons, Inc., 2010; pp 732.

[25] van Meerloo J, Kaspers GJ. Cloos J. Cell sensitivity assays: the MTT assay. Methods in molecular biology (Clifton, N.J.), 2011;731:237-245.

[26] Llorent-Martinez EJ, Zengin G, Fernandez-de Cordova, ML, Bender O, Atalay A. Ceylan R., et al. Traditionally Used Lathyrus
Species:Phytochemical Composition, Antioxidant Activity, Enzyme Inhibitory Properties,Cytotoxic Effects, and in silico Studies of L. czeczottianus and L.nissolia. Front Pharmacol 2017;8:63

[27] Naydenova ED, Todorov PT, Topashka-Ancheva MN, Momekov G, Yordanova TZ, Konstantinov SM, et al. Novel N (phosphonomethyl) glycine derivatives: Design, characterization and biological activity, Eur J Med Chem 2008;43:1199-1205.

[28] Matilla B, Mauriz JL, Culebras JM, González-Gallego J, González P. Glycine: a cell-protecting anti-oxidant nutrient, Nutr Hosp 2002;17(1):2-9.

[29] Ladas EJ, Jacobson JS, Kennedy DD, Teel K, Fleischauer A. Kelly KM. Antioxidants and cancer therapy: a systematic review. J Clin Oncol 2004;1;22(3):517-28.

How to cite this article: Mesci S, Gul M, Yildirim T. Antioxidant and Cytotoxic Activity Studies of Sulfur Containing Glycine Imine Derivatives MCF-7 and DLD-1 Cell Lines. Clin Exp Health Sci 2021; 11: 81-90. DOI: 10.33808/clinexphealthsci.787954 